\title{
Reviews
}

\section{Busfield, Andrea. Born. Under a Million Shadows. London: Black Swan, 2009.}

\author{
Reviewed by Bill Phillips \\ University of Barcelona
}

In April 2009 the publishers Black Swan brought out Andrea Busfield's first novel, Born Under a Million Shadows. It has since been translated into a number of different languages, including Spanish, Chinese and German and, unusually for a first time author, it is being heavily publicised. In Spain, for example, El Periódico de Catalunya has carried half page advertisements promoting the book, most recently on October $10^{\text {th }}$. Both the advertisements as well as the cover of the novel itself depict a young Afghan boy running with his head over his shoulder, presumably flying a kite. The background is layered in yellow, brown and green, and the title is printed in a shiny brownish gold script resembling unjoined up handwriting. Anyone familiar with Khaled Hosseini's bestselling novels The Kite Runner (2003) and A Thousand Splendid Suns (2007), both of which have been filmed (The Kite Runner was released in 2007 while A Thousand Splendid Suns is scheduled for release this year) will immediately be alerted. The similarity with the cover of $A$ Thousand Splendid Suns, with its title printed in a shiny brownish script resembling unjoined up handwriting and its picture of a girl walking against a layered background of yellow and brown is clearly no coincidence. Despite Andrea Busfield's assertion, then, in The Observer, in April of this year that "I don't think you could find two more different books than The Kite Runner and Born Under a Million Shadows," her publishers clearly disageree: Black Swan are making every possible effort to sell Busfield's work on the back of Hosseini's runaway success.

But are the novels comparable? Hosseini's, written in deceptively accessible prose, are carefully crafted to expose the horrors of life for many Afghans in recent decades from the point of view, mainly, of children. The Kite Runner takes place both in Afghanistan and the USA, though mainly the former, and describes the friendship between two boys of different social class and ethnic origin. A Thousand Splendid Suns, meanwhile, traces the tragic lives of two women, Mariam and Laila, as they struggle to survive under the oppressive political and religious regimes dominating Afghanistan for the last fifty years. Much of the power and authenticity of Hosseini's narratives would seem to be attributable to the fact that he was born and spent the first twelve years of his life in Afghanistan before the family moved into exile, first in Paris, and then the United States.

Andrea Busfield is a British journalist whose experiences over a three year period in Kabul provided her with the material for her book. Both authors, therefore, have first hand experience of the country, one as a native, the other as a foreign resident and indeed, this is how the novels are focussed. Fawad, the child protagonist of Busfield's novel, moves into a house occupied by three foreigners: James, a drunken journalist, May an engineer and Georgie who works for an NGO. Busfield says that:

I wanted to show that members of the international community are not just people looking to earn filthy money and not giving a damn about the country. A lot of them are very committed, very 
trustworthy, honourable, fantastic people. They do mix with locals and locals do mix with them and everybody does get on to a certain degree (Observer).

The three expatriates' characters are carefully chosen to demonstrate that, despite the apparent moral weaknesses of the West, Afghanistan is fortunate to have them. James, the drunkard, who introduces Fawad to beer with predictable results is, despite his unislamic propensity for alcohol, really both a good man and a good journalist: the freedom of the press being, of course, one of the bulwarks of western civilisation and sadly lacking in ideologically totalitarian societies such as Afghanistan. May, as well as being an engineer, is a lesbian, and why not? Except one rather suspects that Busfield is heavy-handedly pointing out that women can be both engineers and lesbians and also be perfectly wonderful people proving that if only the Afghans would wake up to this fact they would be much better off. As no doubt they would. Georgie, one of the central characters of the novel, is also a bit of a drinker, and something of a feminist (with an Enid Blytonish boy's name, just to make sure the reader is aware of her refusal to satisfy traditional gender specific expectations). She is a woman determined to live life under her own terms, just as one can in the West, unlike in Afghanistan, which is very backward in comparison and thus in dire need of enlightened foreigners whose mere presence is justifiable for their freedom-loving ways.

Fawad, of course, is fascinated by these strange yet liberated people and inevitably his contact with them slowly opens his eyes to his own ignorance and prejudices. None of this, however, is the real plot. The novel is really a love story, a romance in the finest Mills and Boon tradition. Georgie, it transpires, is in love with Haji Khan, one of the most powerful and feared men in the land, a man whose "voice was deep and low [which] suited his face which was strong and framed by thick dark hair, a trim black beard and heavy eyebrows" (Busfield 66). In true Byronic style Haji Khan is also described as "the scourge of the Taliban, the son of one of Afghanistan's most famous Mujahedin, and now one of the country's biggest drug dealers" (Busfield 85), the latter charge, of course, proving to be false as the story progresses. He too, is in love with Georgie, but their love is doomed: her principles will not allow her to submit to the degradation of being a Muslim wife, while he cannot allow his position to be undermined by marriage to an immoral infidel: "I'm a Godless kafir, Fawad. Khalid's a Muslim. How is that even possible in today's Afghanistan?" (Busfield 184) asks Georgie, rhetorically. To be fair to Busfield she recognises the melodramatic nature of the story she has chosen to unfold and there are constant references to Indian and Afghan films and television series. According to Fawad, Haji Khalid "looked like an Afghan film star, and I hated him for it" (Busfield 66) while in a later scene he "walked down from his bedroom looking like he'd just got off a film set" (189). At one point Fawad and his mother specifically compare Georgie's problems with "the Tulsi soap opera that came from India", a programme which "finished in another explosion of tears and sad music" (Busfield 250). Not, indeed, that the comparison is unfitting. Later on Georgie is courted by doctor Hugo, an Englishman of the old school, who believes it his duty to inform Haji Khalid that he intends to marry Georgie. Khalid is suitably outraged and screams: "You think you're in love with Georgie? You think? Well, let me tell you something: I am Georgie! That woman is my heart; she is locked in my bones, in my teeth, even in my hairs. Every inch of her is me and every inch of her belongs to me," (Busfield 326) before throwing the doctor to the ground. Clearly, prior to succumbing to 
Indian soap opera, Busfield had been brought up on a strict diet of nineteenth century romance (not that, as certain Bollywood films demonstrate, there is much difference). "My love for Heathcliff resembles the eternal rocks beneath: a source of little visible delight, but necessary. Nelly, I am Heathcliff! He's always, always in my mind" (Emily Brontë 82), cries Cathy in Wuthering Heights, revealing the canonical nature of the reading informing Busfield's writing. And why not? Kate Bush got away with it, after all.

Such a mountain of obstacles to be overcome: how are Georgie and Khalid ever to be united as man and wife? "Do you imagine," Fawad is told, "even if she converted to Islam, that Georgie could live life as the wife of a high Pashtun man, locked behind the walls of her home, unable to go out, unable to see her male friends, unable to work? It would kill her." And as for Khalid, if "he left to live with a foreign woman, how could he ever return and still keep the respect he and his family have earned over all these terrible years? He would have to live in virtual exile, and that would destroy him" (Busfield 230). Marriage then, either abroad or in Afghanistan, would kill them. What could be more romantic? As the book reaches the final pages Khalid's compound is attacked and Georgie shot. With her life "pouring from her body like a river" (Busfield 370), she selflessly makes a deathbed conversion to Islam at the hysterical behest of Fawad, who believes she will otherwise surely spend eternity in hell, and then "she closed her eyes and Georgie was gone" (Busfield 371). Except she wasn't. Severely wounded, it is true, indeed so much so that "she couldn't give him children because her insides were damaged." Yes, reader, she married him "because it was a true love story and they had become famous in the province" (Busfield 381).

My reference to Jane Eyre's quietly triumphant words "Reader, I married him" (Charlotte Brontë 518) is not idle. Only through Rochester's mutilation - his loss of sight and use of his left arm, together with Jane's fortuitous inheritance from her uncle - are they able to overcome the social, economic and gender inequalities that have so far kept them apart. Regardless of his marriage to Bertha Mason, Rochester is simply beyond Jane's reach. Since Charlotte Brontë "can only imagine marriage as a union with a diminished Samson" (Gilbert \& Gubar 368), in order for Jane to marry Rochester he must be brought down to her level. Similarly, in order for Georgie to marry Khalid, she must be brought down to his. Conveniently converted to Islam through the intercession of the child Fawad, unencumbered by the spiny question of how to bring up their children, and somewhat slowed down, no doubt, by her injuries, Georgie can now submit to the subordinate role of Muslim wife even if "she sometimes worked for a company in Kabul - and, even worse than that, men would come to her home who weren't male relatives" (Busfield 380).

The contrasting representations of Afghans and foreigners is stark in Born Under a Million Shadows. As Busfield says in the Observer article: "I'm still terribly in love with the place; I think it's fantastic, [...B] ut you can only live there for three years before you start to lose your mind." Only by becoming less than the woman she was can Georgie marry Khalid and remain in Afghanistan. The foreigners, despite their carefully selected foibles and eccentricities are the models for a future, more enlightened, happier race of Afghans. The cream of the latter, meanwhile, is a stereotype; the hero of a Bollywood bodice-ripper. To give her her due, Andrea Busfield is right: there is no comparison between Born Under a Million Stones and the novels of Khaled Hosseini, whatever her publishers might want us to think. 
Economic considerations aside, in inviting comparison between her work and Hosseini's, they have done her a disservice.

\section{References}

Brontë, C. (1847): Jane Eyre. London: Penguin, 2006.

Brontë, E. (1847): Wuthering Heights. London: Penguin, 1995.

Busfield, Andrea (2009): Born Under a Million Shadows. London: Black Swan.

Gilbert, S.M. and Gubar, S. (1979): The Madwoman in the Attic. Second Edition. New Haven and London: Yale UP, 2000.

Hosseini, Khaled (2003): The Kite Runner. London: Bloomsbury. . (2007): A Thousand Splendid Suns. London: Bloomsbury.

Smith, David (2009): “The Upside of Afghanistan” The Observer 19 April.

Spain's Long Shadow: The Black Legend, Off-Whiteness, and Anglo-American Empire. María DeGuzmán. Minneapolis: University of Minnesota Press, 2005. Pp. ix +372.

Reviewed by Jenny Heil

Emory University

Scholars have attempted to de-center the United States from American Studies in recent years by studying instead the phenomenon of the shadow, whether cast by an Anglocentric United States onto other nationalities or vice versa, in an effort to complicate ideas about nationalism and to promote better understandings of hemispheric and/or transatlantic interactions. María DeGuzmán's monograph Spain's Long Shadow: The Black Legend, Off-Whiteness, and Anglo-American Empire participates in this turn in what she calls the New Americas studies by destabilizing the traditional black/white racial binary to reveal how an Anglo-American imperial identity has been mediated across the Atlantic through U.S. representations of Spain as not-quite-white. She sketches the history of this off-whiteness from the late eighteenth century to the twenty-first by exploring the implications of how and why the two major forms racializations of Spain took - the alien white darkened by the Black Legend and the Orientalized racial other-change over time. DeGuzmán appropriates the metaphor of the long shadow not only to describe Spain's historically imperial past (as indicated by the book's main title Spain 's Long Shadow) but more importantly to underline how artists conceived of the U.S.'s own emergent empire in contradistinction to Spain's supposedly more brutal one (indicated by the subtitle The Black Legend, Off-Whiteness, and Anglo-American Empire). By focusing largely on canonical U.S. writers' representations of Spain, particularly in the first four of six chapters, DeGuzmán does not de-center the United States from this New Americas studies monograph, but she does use that focus to problematize notions of "America" that equate it with the territorial United States and to historicize how the U.S. came to be at the center of American Studies in the first place. Indeed, one of the assets of this monograph is that DeGuzmán foregoes a study of the "Hispanophile" authors (i.e., Washington Irving, 
William H. Prescott, George Ticknor), which one would typically expect from studies of Hispanism in the U.S., to reveal how entrenched Spain was in the imagination of other U.S. writers who have not hitherto been considered part of this movement.

In order to elaborate a more nuanced formulation of Anglo-American (imperial) identity, DeGuzmán relies on the psychoanalytic concept of the imago or alter ego, of which Spain is that "image in the mirror, as a rival idealized and therefore demonic body" in contrast to the more benignly figured American, that is Anglo-U.S., ego (xvii). As Spain's gubernatorial power in the Americas declined during the nineteenth century, its symbolic power in North America as imperial alter ego increased, and DeGuzmán traces this development in chapters organized by chronology and pseudo- to outright-racializations of things "Spanish." Prior to the late nineteenth-century consolidation of an Anglo-American imperial identity with the U.S. defeat of Spain during the Spanish-Cuban-American War, which DeGuzmán discusses in chapter three, a still-fluid Anglo-American identity cohered around two ideas of Spain: the alien white conquistador/knight/discoverer and the Moor/Gypsy/Indian racial other, which DeGuzmán discusses respectively in chapters one and two. Through close readings in chapter one of Charles Brockden Brown's Wieland, Edgar Allan Poe's "William Wilson" and "The Pit and the Pendulum," and Herman Melville's Benito Cereno, DeGuzmán shows how early nineteenth-century "American" fiction in the Gothic mode deployed the Black Legend, which posited that the Spanish colonial project was more nefarious than that of England, to morally blacken Spaniards in a proto-racialization that did not become separated from AngloAmericanness until the latter part of the nineteenth century as tensions rose between Spain and the U.S. over Cuban territory. By analyzing in chapter two the historical romances The Yemassee by William Gilmore Simms, The Scarlet Letter by Nathaniel Hawthorne, Elsie Venner by Oliver Wendell Holmes, and the iconic El Jaleo by John Singer Sargent, DeGuzmán shows how by the mid-nineteenth century, Spain's ethnically mixed past in Europe and in the Americas (among Moors, Gypsies, Jews, Native Americans, and Africans), became a threatening presence against which justifications for a more ethnically pure U.S. expansion were made. Chapter three incorporates gender and class into this study of how race, by the close of the nineteenth century, more virulently factored in the compounding of a U.S. empire. DeGuzmán discusses how people of all classes, and women in publicly recognized roles, were subdued as potential threats to the internal order of the U.S. by co-optation into its imperial cause against the external enemy: Spain.

Particularly strong is chapter four in which DeGuzmán examines early twentieth-century representations of Spain by Gertrude Stein, Ernest Hemingway, and Richard Wright to argue convincingly for its totemic influence on the Modernist movement, thereby revising accounts of Modernism that more usually study France's influence on U.S. authors. Chapters five and six take this study through the second half of the twentieth century by focusing on the fiction, photography and film of Kathy Acker, Xurxo Lobato, Fernando Colomo, and Floyd Salas, among others, not only to reveal how the Spaniard figured as alien white and Oriental other became tied together in intricate ways but also to show that such complicated figurations of Spain are sometimes - but not always - deployed to deconstruct nationality as essentialized identity itself.

From the site of a prior and problematic Spanish imperialism (before the period of this 
study), to a waning empire figured as alter ego to a waxing U.S. empire (during the nineteenth century), to a vanquished other with whom postcolonials have begun to identify (during the twentieth century), DeGuzmán shows that despite such late-twentieth century identifications with Spain, "the recycling of certain kinds of figurations of Spain in the mid-1990s symptomatizes the cycling and continued life of empire, in this case Anglo-American imperial ideology" (303). While this argument appears, at times, to overdetermine DeGuzmán's analysis, the strength of Spain's Long Shadow lies not only in lucid close readings of such literary texts as Stein's Autobiography of Alice B. Toklas, The Geographical History of America, and Paris France but also in its insight into other media, such as paintings, photography and political cartoons. Moreover, DeGuzmán's work exemplifies the potential of interdisciplinary scholarship, particularly between American and Latina/o Studies, for which Spain 's Long Shadow is a helpful foundation. With her intervention, American Studies scholars can no longer ignore or deny the central importance of Spain to the history and continuing development of an Anglo-American imperialism.

\section{The Edgar Allan Poe Review. FALL 2009 VOLUME X, NUMBER 2}

Reviewed by Silvia Molina

Polytechnic University of Madrid

Funded by the "Poe Studies Association" and printed at Saint Joseph's University (Pennsylvania, USA), The Edgar Allan Poe Review contains in its Fall 2009 issue a series of interesting and enlightening essays written on the occasion of the bicentennial which commemorates the birth of Edgar Allan Poe. Margarita Rigal and Beatriz González act in this issue as guest editors for the "Spanish" essays.

The part of issue edited by Rigal and González opens with a section entitled Poe in Spain on the Occasion of His Bicentennial and includes two essays that link Poe with two Victorian writers. The first one, Plagiarism in Poe: Revisiting the Poe-Dickens relationship by Fernando Galván highlights the influence Dickens' works exerted on Poe's theory of the short story, the unity of effect and on some of Poe's well-known works such as "The Tell-Tale Heart", "The Black Cat", "Ligeia” or the famous poem "The Raven" among others. The latter is fairly similar to Barnaby Rudge. In Dickens' novel we can read the description of the link between the mentally retarded Barnaby and his raven, "Grip", both living at the Newgate prison. Galván finds other echoes in Poe's "the Raven" such as the repetition of the raven's words, the repetition of "hope", the reference to melancholy, etc. However, Galván clearly points out that this does not strictly mean plagiarism. The ideas and motifs that shape "The Raven" have their origins in Dickens but "Poe managed somehow to develop and improve them in his unforgettable poem" (page 19). Galván proves with other well chosen examples from the tales and the poems that Poe was certainly sensitive to some of Dickens's ideas, narrative constructions and rhetorical and stylistic aspects. Galván concludes in his thoughtprovoking study that Poe created new works sometimes superior to his sources and that means " a conscious, careful and patient combination of a diversity of materials and techniques, 
carried out understandingly, as Poe liked to define genuine originality" (page 20). The second essay, Sir Arthur Conan Doyle and the Hauntings of the “American Blood-Curdler", by Beatriz González-Moreno examines Poe's impact on Arthur Conan Doyle's Gothic tales. González emphasizes the fact that Dupin was not Doyle's only source of inspiration nor was Holmes his only creation. González brings her thorough study to a close saying that Poe always haunted many of Doyle's stories and Doyle never ceased acknowledging his debt to the spirit of the "American blood-curdler" (page 32)

The second part, "Poe's legacies in Spain" includes six original articles focusing on Poe's reception in Spain from 1850s until the present. The first article of this part, written by Margarita Rigal, Spanish “Misreadings" of Poe's Life and Works at the Beginning of the Twenty-First Century, proves how Poe has been misread both by Spanish readers and researchers for more than a century and a half. Poe was first alluded to in Spain by writer Cecilia Böhl de Faber (1796-1877) in a letter she sent in 1856 to fellow author Juan Valera (1824-1905). From this first mention, Rigal proposes a well-documented chronology of Poe's legacy in Spain which finishes in 2002 with Poe, un cuento musical de miedo [ Poe, A Terror Musical Tale] by the famous Spanish drama company Dagoll Dagom. This study is a valuable contribution for understanding Poe's reception in Spain.

The Second Article, Edgar A. Poe's Poetry in Spain in the $19^{\text {th }}$ Century: An Issue for Connoisseurs, by Santiago Rodríguez deals with the response to Poe's poetry in Spain during the $19^{\text {th }}$ Century. The author concludes that cultural misinterpretations due to an insufficient knowledge of British and American Romantic poetry were common in the $19^{\text {th }}$ Century, for example, when Poe was compared to Lord Byron. Poe was viewed only as an exotic writer of bizarre stories.

The third article, The Treatment of Sight in Edgar Allan Poe and Gustavo Adolfo Bécquer, by Ricardo Marín-Ruiz concentrates on how both Poe and the Spanish Romantic writer Bécquer (1836-1870) treated visual sensations. Marín-Ruiz provides evidence that Poe addresses the symbolism pertaining sight with a focus on death and supreme intelligence. In Bequer's writings, death and superior intellect do not only manifest themselves through the luminosity of the eyes, but also through their color; green and blue are the most recurrent hues in Becquer's stories and poems.

The fourth article, Poe's "Maison de Santé" Revisited: A Spanish Imitation of "The System of Dr. Tarr and Professor Fether”, by José R. Ibáñez is a detailed analysis of the relations between "The System of Dr Tarr and Professor Fether", a story where humour and uncertainty are intertwined, and a Spanish tale entitled "Siete historias en una" [Seven stories in one] written by the now almost forgotten short story writer, José Fernández de Bremón.

The fifth article, Finishing “The Lighthouse” with José Jiménez Lozano: A Sample of Edgar Allan Poe's Influence on the Contemporary Spanish Writers, by Emilio Cañadas investigates the influence of Poe on a contemporary Spanish writer José Jiménez Lozano, examining Lozano's proposed ending to Poe's "The Lighthouse". The author concludes that Lozano provides a remarkable presentation of the influence of Poe in contemporary Spanish writers.

This part closes with The Influence of E. A. Poe in the Spanish Short Subject Industry, by Isabel Jiménez and Ángel Galdón is a study of the most recent impact of Poe's works on 
Spanish popular culture. Both authors wrap up their study stating that Poe's plots and topics have influenced the cinematographic culture of the Spanish people in the last years.

The third section of the review, for which the guest editors were not responssible, consists of miscellanea:

First, The Orientalization of John Winthrop in “The City in the Sea” by López discusses the influence of Winthrop in Poe's vision of a utopian city gone wrong. Poe's "The City in the Sea" could be an Orientalization of Winthrop's city on a hill, even if Poe never heard of a "A Model of Christian Charity" nor even knew who Winthrop was, because the cultural forces behind both metaphorical cities were so ubiquitous and potent.

Ships and Crypts: The Coastal World of Poe's "King Pest", "The Premature Burial", and "The Oblong Box" by Dan Walden explores the influence of the maritime culture in these stories. Walden proves how the realities of the coast in the third decade of the $19^{\text {th }}$ century were far removed from the idealistic frontier of American opportunity that the coast represented in the years surrounding the War of 1812 . He concludes that the coast's location between the commonly knowable world of land and the unfathomable world of the sea increasingly came to be conceptualized as a Gothic frontier, and Edgar Allan Poe skilfully adapted the reality of the coastal life to create dark and disturbing stories.

Lastly, A Further Note on Lawrence Labree, by Kent Ljungquist studies how this editor of the New York Rover, discusses the topics of originality plagiarism in the Poe-Longfellow war.

The final section of this issue is five reviews of Poe's scholarship: Richard Kopley's Edgar Allan Poe and the Dupin Mysteries by Benjamin F. Fisher; Jack Mircala's Siniestras Amadas: 22 Delirios necro-románticos de Edgar Allan Poe by Ana González-Rivas Fernández and Christopher Rollason; BRAT Productions. Haunted Poe by Cynthia Popper; An Intimate Evening of Poetry and Conversation with John Astin by Jonathan Hartman and Edgar Eeckman's The Murder(s) of Edgar Allan Poe by Jan Vander Laenen.

All in all, the interest of the book lies in the new topics covered and should be of concern to all those scholars interested in Poe's writings. The contributors provide original insights into Poe's short stories and relationships with other writers and other cultures. 